\title{
Dedektif Romanları: Tarihine Sığmayan Geçmişi İle Türkiye'de ve Dünyada Adli Edebiyat
}

\author{
The Detective Fiction: Forensic Literature in Turkey and The World with Its \\ Implacable Historical Background
}

\author{
Reyyan A $\breve{g} a o g ̆ l u^{1}$, Gökhan Oral ${ }^{2}$ \\ ${ }^{1}$ İstanbul Üniversitesi Adli Tıp Enstitüsü Sosyal Bilimler Anabilim Dalı, İstanbul \\ ${ }^{2}$ İstanbul Üniversitesi Cerrahpaşa Tıp Fakültesi Adli Tıp Anabilim Dal, İstanbul
}

\begin{abstract}
Özet
Dil ile söylem bir bütündür; edebi eserler yolu ile söylemin bir parçasını oluşturan ve tarihsel, sosyal, psikolojik birçok olgu hakkında bilgi veren edebiyat, Dilbilim dışındaki bilim dalları tarafından da incelenmektedir; multidisipliner bir özelliğe sahip olan Adli Bilimler de bu bilim dallarından biridir. Polisiye, edebiyatın bir parçasını oluşturduğundan, bu parçanın Adli Bilimler ile ilişkisi kaçınılmaz derecede ön plandadır. Zira insanoğlunun ortaya çıkışından itibaren, suç olgusu insanlığın yaşantısında yer tutmakta, bu durum edebi eserlerde de kendini göstermektedir. Suç-suçlu-araştırmacı üçgeninin oluşturduğu polisiye, böylesi bir dünyada Adli Bilimler'in yararlandığ 1 bir kaynak mahiyetindedir. $\mathrm{Bu}$ çalışma, polisiyenin Türk ve dünya edebiyatındaki konumunu değerlendirerek, polisiyenin gelişim evrelerini incelemek için gerçekleştirilmiştir.

Çalışma kapsamında literatür taraması yapılmış, polisiyenin gelişim evrelerinin Türk ve dünya edebiyatındaki izi sürülmüştür. Bu bağlamda nitel bir çalışma hazırlanmış ve Türk ve dünya edebiyatında hüküm süren polisiye kültürünün en önemli ve canlı eserleri, kronolojik bir şemada toparlanmıştır.

İnceleme sonucunda, polisiyenin doğuşunun polis gücünün etkisi ile geçekleştiği, tarihe adını yazdırmış polis ve dedektiflerin günümüzde hâlâ gizemini koruyan edebi eserlere 1şık tuttuğu bilgisine ulaşılmıştır.
\end{abstract}

Anahtar Kelimeler: Edebiyat; Adli Bilimler; Polisiye; Suç.

Edebiyat, bireylerin yaşam hakkında söz söyleme sanatıdır. Söyleyeceği olan yazar, bazen bir öykü, bazen bir şiir, bazen bir roman ile düşüncelerini aktarır. Önemli olan aşikâr olmayanı dillendirmektir. Bu dillendiriş gelişi güzel gerçekleşmemektedir elbette. Söz konusu eserin

Sorumlu Yazar: Öğr. Gör. Reyyan Ağaoğlu

İstanbul Üniversitesi Adli Tip Enstitüsü Sosyal Bilimler Anabilim Dalı Yüksek Lisans Öğrencisi, İstanbul

E-mail:agaoglureyyan@gmail.com

Geliş: 28.05.2018 Düzeltme: 26.06.2018 Kabul: 14.08.2018

\begin{abstract}
Language and discourse constitute a whole; literature, which forms a part of discourse through literary works and suggests an idea about so many facts just like historical, social and psychological events, is studied by other disciplines besides Linguistics; Forensic Science, having a multidisciplinary feature, is one of them. As the detective fiction forms a part of literature, the relationship of this part with Forensic Sciences inevitably remains at the forefront. Throughout the emergence of human beings, crime occupies a place in the life of the mankind and this issue manifests itself in literary works. The detective fiction, formed through crime-criminal-detective triangle, is a source by which Forensic Sciences profit. This study is carried out to investigate developmental stages of the detective fiction by assessing the position of the detective fiction in Turkish and world literature.

In the scope of the study, a literature review was made and developmental stages of the detective fiction in Turkish and world literature were traced. In this regard, a qualitative study was prepared and a chronological schema which reveals the most important and lively works of Turkish and world literature was created.

At the end of the study, it was learned that the detective fiction emerged through police power and the policemen and the detectives, who had left their marks in history, set light to literary works which still remain a mystery.
\end{abstract}

Keywords: Literature; Forensic Sciences; Detective Fiction; Crime.

yazarın yaşadığı döneme, etkilendiği düşünce akımına vurgusu kaçınılmazdır. Bir edebi eser türü olan polisiyenin de bu gerçeklikten aldığı pay göz ardı edilemez. Zira insanoğlunun yaşadığı çevre, modernleşmenin etkisi ile kirlenmekte ve suç unsuru gittikçe artmaktadır (1). Polisiye, suçun yarattığ 1 yıkımı bünyesinde barındırır; anlatılan suç, toplumsal barışı ve güvenliği tehlikeye sokmakta ve insanlar arasında güvensiz ve huzursuz bir atmosferin doğmasına neden olmaktadır. İşte bu noktada devreye giren dedektif, kendine has yöntemler vasıtasıyla toplum- 
sal düzeni yeniden kurarken, sistemsel ve hukuki sürecin destekçisidir (2). Dolayısı ile polisiyenin görevi modernleşen dünya içerisine sıkışıp kalmış, suç ile çepeçevre sarılmış bireyin yanlışlarla örülü çevresini dışarıdan bir göz ile aktarmaktır.

Dünya edebiyatı göz önüne alındığında polisiyenin başlangıç noktası Edgar Allan Poe'nun Morgue Soka$\breve{g}$ l Cinayetleri adlı eseridir (1). Eserde, birlikte yaşayan anne ve kızının hunharca katledildiği faili meçhul cinayetin öyküsü anlatılır. Cinayeti soruşturarak polisiye okuru ile buluşan C. Auguste Dupin'in soruşturma süresince izlediği yol, arkadaşı tarafindan okurla paylaşılır. Olay yerini inceleyip tanıklarla görüşerek suçluya dair bir profil çıkartan Dupin, cinayetin nasıl ve neden işlendiğini ortaya çıkartır (3). Böylece polisiye içeriğini oluşturan suç-suçlu-araştırmacı üçgeni Morgue Sokağı Cinayetleri aracılığı ile kurulmuş olur (1). Poe, polisiye eserlere suç-suçlu-araştırmacı üçgenini katmakla kalmaz; Marie Roget'in Esrarl (1842) ve Çalınmış Mektup (1845) eserleri ile bir polisiyenin izlemesi gereken sıralamayı oluşturur (4). Buna göre polisiye, dedektifin tanıtılması, suçun işlenmesi ve ipuçları, araştırma ve soruşturma, çözüm, çözüme giden delillerin açıklanması ve sonuç bölümlerinden oluşmaktadır (1).

İngiltere, dünya devletleri arasinda ilk profesyonel polis gücünü kuran devlet olmuş ve bunu 29 Eylül 1829'da gerçekleştirmiştir (5). Şüphesiz ki İngiltere'nin suçu önlemek için başlattığı bu süreç, Poe'yu da etkilemiş ve ilk polisiye eser olma özelliğini taşıyan Morgue Sokağl Cinayetleri'ne destek vermiştir, zira Poe, polisiye türünü 1841 'de yazdığı Morgue Sokağg Cinayetleri ile ortaya çıkarmıştır (6). Söz konusu tarihler göz önünde bulundurulduğunda, Poe'nun ilk polisiyeyi ilk profesyonel polis gücünün kurulmasından sonra yazdığ aşikârdır. Bu bağlamda polis gücünün ortaya çıkış sürecinin basamaklarını incelemek doğru olacaktır. R. J. Terrill, World Criminal Justice Systems: A Survey adlı inceleme kitabında, İngiltere'nin suç ile mücadele evresinde geçirdiği süreçleri konu alır ve bu süreci özetler. Terrill'a göre, İngiltere'de hüküm sürmüş olan en eski suç önleme sistemi "tithing", bir diğer adı ile "on ailelik yönetim bölgesi”dir. Anglosakson sistemin benimsendiği bu yöntemde, bireylere ait görev ve yükümlülükler söz konusudur. Sistemde, on kişilik gruplara ayrılan bireylerin her biri birbirinden sorumludur ve herhangi birinin işlediği suç diğer grup üyeleri tarafindan tespit edilir. Sorumluluk Kral'ın yerel temsilcisi olma sıfatı ile Şerif'tedir; dolayısı ile Şerif, Ortaçağ başlarında adalet sisteminin merkez ile arasındaki bağdır. Güvenlik güçleri ile ilgili ikinci önemli adım ise İngiltere'nin feodal sistemle kurduğu bağlantı sonucu ortaya çıkmıştır. Lordlar, ekonomik ve sosyal gü- venlik nedeni ile topraklarında çalışan bireylerin korunması için bir takım kişiler görevlendirmiş ve taşra polisi bu şekilde oluşmuştur. On ailelik yönetim bölgesinin yerini alan taşra polisi, feodalite egemenliğini yitirdiğinde dahi varlığını korumuştur. Zira Kral, imparatorluğun bekası için güvenlik güçlerinin önemli olduğu kanısındadır ve bu sebepten, taşra polisleri şimdiki İngiliz güvenlik güçlerinin temellerinin atılmış olduğu 1285 Winchester Yasası'nda tanımlanır. 17. yy'ın sonu, 18. yy'ın başlarına kadar gelen bu sistem, gelişen toplumun etkisi ile yetersiz hale gelir. Toplum gelişip genişledikçe, suç oranları artmakta ve var olan düzen yoğun bir eksiklik barındırmaktadır. 18. yy ile birlikte, İngiltere'de hüküm süren monarşinin gücünü arttıracağından korkan bir kısım politikacı, güvenlik güçleri ile ilgili düzenleme yapılmasını talep eder. Lâkin Parlemento'da görev yapan çoğunluk, monarşinin güç kaybetmesini istememektedir; dolay1s1 ile talep edilen düzenleme kabul edilmez. 1820'lerde ise, özellikle Londra'nın metropolit bölgelerindeki polis gücünün yetersizliğini dile getiren birkaç politikacı sayesinde, 29 Eylül 1829 'da, “yeni polisler”, Londra'nın metropolit sokaklarında devriye gezmeye başlar. Böylelikle İngiltere'deki bu oluşum, dünyanın çoğu bölgesinde ilk modern polis gücünün tanımı haline gelir (5).

İngiltere'nin polis gücüne dair gerçekleştirdiği bu atılım, birçok ülkeyi etkilediği gibi, ülke vatandaşlarını da etkilemişti. Zira ülke içerisinde hüküm süren kargaşa ve güvensizlik ortamı belli bir gücün etkisi ile ortadan kaldırılmaya çalışılıyordu; kargaşa ve dinginlik, güvensizlik ve güven arasında kalan bölgeye hâkim bir kuvvet söz konusu idi. Poe, ilk dedektif romanı mahiyetindeki eseri Morgue Sokağı Cinayetleri'ni yazdığı zamanlarda, İngiltere'nin polis gücü ve suç önleme olgusu ile ilgili çalışmaları, yukarıda değinildiği üzere çok önceden başlamıştı ve çalışmalar geliştiriliyordu. Dolayısı ile Poe, kaçınılmaz olarak, suç ile mücadelede etkinleştirilmeye çalış1lan polis gücü ya da ikincil gücün hâkimiyetini, eserinde, Dedektif Dupin ile yansitmaktaydı. İngiltere'de bu gelişmeler yaşanırken, Poe'nun ülkesi Amerika'da ise karışıklıklar ve güvensizlik hüküm sürmekte idi. Sophie Body- Gendrot'un The Social Control of Cities: A Comparative Perspective adlı eserinde de değindiği üzere, Amerika'da 1960'ların sonuna kadar iki topluluk vardı: Amerikan ekonomisini güçlendiren birinci topluluk ile sosyal haklardan yoksun ikinci topluluk. Çoğunluğun siyahilere ve melezlere uyguladığ ${ }_{1}$ baskı, şiddet ve önyargı abartılamayacak derecede yoğundu. Bunca baskı, şiddet ve önyarg1, Amerika'da da İngiltere'de olduğu gibi kar1şıklıkların vuku bulmasına neden oluyordu. Bu karışıklık, ülkede suç olgusunun artışının temel nedenlerindendi. 19. yy ile birlikte, sanayileşen Amerika'da, söz konusu ikinci 
topluluk iyiden iyiye açlık ve sefalet içerisine düşmüş, ülkenin kuruluşundan beri hüküm süren yoğun karışıklık artmış, böylelikle tam da bu dönemde, 1890 ile I. Dünya Savaşı arasında, suç önleme isteği ortaya çıkmıştı (7). 1890'lara kadar güvenlik güçleri konusunda doğru düzgün bir çalışma yapılmamış olan Amerika'da polis gücü işte bu şekilde kurulmuş oldu (8).

Polisiye romanlar dikkate alındığında, polis gücünün gelişiminin yanı sıra cinai eserlerin de polisiye roman kültürüne etki ettiğini söylemek yanlış olmayacaktır. Zira insanoğlu, doğası gereği şiddet ile etkileşim içerisindedir ve edebi eser niteliği taşıyan çoğu eserin insanoğlunun karıştığı suçları konu aldığı görülmektedir. Edebiyat tarihi incelendiğinde görüleceği üzere, suç olgusuna gönderme yapan birçok eserin ilk polisiye roman olan Morgue Sokă̆l Cinayetleri'nden evvel topluma kazandırıldığı aşikârdır.

Kitab-ı Mukaddes'te anlatılan Habil ile Kayin vakası, Kayin'in erkek kardeşi Habil'i öldürmesini konu alır ve insanoğlunun ilk cinayetine değinir (9). Dolayısı ile Kitab-ı Mukaddes bir cinai eser özelliğine sahiptir. Sofokles'in Kral Oedipus'u da cinai eserler arasında gösterilebilir. M.Ö. 5. yy ortalarında doğmuş olan Sofokles'in kahramanı Kral Oedipus, Sigmund Freud'un ünlü teorisi Oedipus Karmaşası'na da ad vermiştir. Sofokles, eserinde, Apollo tarafından lanetlenmiş olan Kral Oedipus'un babasını öldürerek annesi ile evlenmeye mahkûm edilişini anlatır (10). Cinai eser yazarlarına bir başka örnek, şüphesiz, William Shakespeare'dir. Şiddet, tecavüz ve intikam konulu Titus Andronicus, Shakespeare'in yazdığ 1 en dikkat çeken cinai eserlerdendir. Eserin kadın kahramanı tecavüze uğrar, dili ve elleri kesilir; Titus Andronicus, oğullarını kurtarmak için sağ elini feda eder, fakat karşılığında eline geçen, oğullarının kesik başı ve kendisine ait elden başkası değildir (11). Tek cinai eseri Titus Andronicus olmayan, birçok eserinde şiddet ve ölüm olgusunu kullanan Shakespeare, Park Honan'in Shakespeare: A Life adlı eserinde değindiği üzere, 1564 yılında doğmuş, 23 Nisan 1616'da ölmüştür (12). Bu pencereden bakıldığında, bir 16. - 17. yy yazarı olan Shakespeare'in de, Sofokles gibi, eserlerini 19. yy'da yazılan ilk dedektif romanı Morgue Sokağl Cinayetleri’nden evvel ürettiği açıktır.

Kitab-l Mukaddes' in ve Sofokles ile Shakespeare gibi yazarların polisiye üzerine etkisini incelerken, bir başka cinai eser olan The Newgate Calendar'in etkisini dile getirmek de yanlış olmayacaktır. Heather Worthington'ın From the Newgate Calendar to Sherlock Holmes adl çalışmasında değindiği üzere, 18. ve 19. yy'da gelişen olayların anlatıldığı The Newgate Calendar, ismini ve konusunu Londra Newgate Hapishanesi'nden alır. New- gate Hapishanesi, suçluların mahkemeye çıkarılmadan evvel kaldıkları yerdir. İngiliz İmparatorluğu kanunlarını çiğneyen bu suçluların çoğu idama mahkûm edilmiştir. The Newgate Calendar' da suçluların yaşamları, suçları, itirafları ve idamları anlatılır. İlk başlarda ucuz kitapçıklar hâlinde satılan, öyküleştirilmiş gerçekler halkı cezbeder. Zira suç olgusu insanları meraklandırmaktadır. 1779'da The Malefactor's Register or the Newgate and Tyburn Calendar adı ile yeniden basılan eser, 1795 'te New and Complete Calendar ismini alır; New and Complete Calendar, 1809'da, editörlüğü Avukat Andrew Knapp ve Avukat William Baldwin tarafından gerçekleştirilerek yeniden piyasaya sürülür. 1826 'da ise The Newgate Calendar adı ile son hâlini alır (13). Suçu, şiddeti, suçluyu ve suçlunun cezai süreçlerini konu alan The Newgate Calendar, 1750 ile 1850 yılları arasında İngiliz vatandaşlarının çoğunun evinde bulunan bir eser olma özelliğine sahiptir; Charles Dickens, Bulwer Lytton ve Henry Fielding'in de aralarında bulunduğu çoğu yazar, bu eseri daha çocukken okumuş ve eserden etkilenmiştir (14). Tüm bu örnekler ışığında, Poe'nun suç ve şiddet konusunda yazılan ilk eserin sahibi olmadığını, verilen örneklerin Poe'nun hayal dünyasını etkilemiş olabileceğini söylemek mümkündür.

Polisiye roman geleneğinin ilk eserini veren yazar, edebiyat tarihinde, Edgar Allan Poe olarak biliniyor olsa da, Poe'yu ve polisiye roman yazarlarını kişiliği, yaşantısı ve dedektiflik hayatı ile etkileyen, yazdığı anılar ile polisiye roman kültürüne giriş yapan, aslında Eugene François Vidocq'tur (15). Vidocq, 23 Temmuz 1775'te Fransa'nın Arras şehrinde doğar (16). William Harrington, Which the Justice, Which the Thief adlı kitabında Vidocq'un yaşantısından bahsetmektedir. Vidocq, henüz çok küęük bir çocukken şiddete ve hırsızlığa yatkınlığı ile dikkatleri üzerine çeker ve ilk hırsızlık deneyimini babasının fırınını soyarak yaşar; bu, hırsızlık hayatını başlatan olaydır. Yıllar içinde yeraltı dünyasının sayılı isimlerinden biri hâline gelir, uzun süre boyunca yaşantısına bir kaçak olarak devam eder ve bu kaçıştan yorulduğu 1809 yılında, "Şeytanî Melek" lakabıyla tanınan Paris Polis Teşkilatı'nın Kriminal Daire Başkanı Mösyö Henry'e teslim olur. Mösyö Henry, Vidocq'u polis casusu olarak kullanmaya karar verir. Mösyö Henry’e güven veren Vidocq, 1811 yılında Brigade de la Surete adındaki Fransiz dedektif servisinin kurucusu olur. Polislerin yalnızca tutuklama ve mahkûmiyet ile ilgilenmesinin doğru olmadığını belirten Vidocq, Fransız suçluların kimlik kayıtlarını, biyografilerini, kişisel ve psikolojik özelliklerini, işledikleri suçlara ilişkin metotları içeren bir arşiv oluşturur; zira ona göre, polisler, çete içine sızarak ve tanıklardan elde edilen bilgileri derleyerek suçu önleye- 
bilirler. Yapmış olduğu tespitlerle günümüz Adli Bilimsel çalışmaların temelini oluşturan Vidocq, 1832 yılında, başkanlığını yaptığı Surete'ten ayrılarak, 1833'te Bureau des Renseignements adını verdiği kendi özel dedektiflik bürosunu kurar (15).

Eugene François Vidocq'un Adli Bilimler ve dedektiflik mesleğine kazandırdıklarının yanı sıra, Fransız edebiyatı ve dedektif romanları üzerine etkileri de yadsınamaz boyuttadır. 1828 yılında basılan eseri Memoirs of Vidocq ile yaşam öyküsünü anlatmış, birçok yazarın bu sıra dişı dedektiften etkilenmesine neden olmuştur (15). Şehirlerde artan suç oranı polis gücüne atfedilen değerin yükselmesine sebebiyet vermiş ve Eugene François Vidocq tarafindan kurulan Brigade de la Surete yapılanması ile dedektiflik mesleği sadece Fransa'da değil, tüm dünyada önem kazanmıştır (17). Bu sebeple, Poe'nun Morgue Sokağı Cinayetleri adlı eseri ile başladığı kabul edilen polisiye akımın ilk kahramanı Dupin, Vidocq'tan etkilenilerek yazılmıştır (15). Zira Dupin, tıpkı Vidocq gibi, soruşturmanın detaylandırılması gerektiğine inanır; faili bulmaya çalışırken gazete haberlerini okur, tanıkların ifadelerinden yararlanır, olay yeri incelemesi yapar; bir başka deyişle, cinayetlere geniş perspektiften bakar (3). Emile Gaboriau'nun 1866 tarihli L'Affaire Lerouge adlı batı dünyasının ilk özgün dedektif romanı sayılan eseri de Vidocq'tan izler taşır. Gaboriau'nun dedektifi Mösyö Lecoq'un ismi gibi agresif tavırları da Vidocq'a göndermedir. Harrington, Which the Justice, Which the Thief 'te, ünlü dedektif karakteri Sherlock Holmes'un yaratıcısı Conan Doyle'un 1885 ve 1886 yılları arasında ortaya çıkan not defterinden bahseder ve Doyle'un en çok etkilendiği dedektif yazarının Gaboriau olduğunu belirtir; bu, Sherlock Holmes'un Mösyö Lecoq tavırlarını anlamlandırmaktadır. Maurice Leblanc'ın Arsene Lupin'i de Vidocq'un etkilediği karakterlerdendir; zira tıpkı Vidocq gibi, Arsene Lupin de suçlu dünyasını terk edip toplum ve iyilik için savaşmaya başlar (15).

Morgue Sokağ Cinayetleri'nin tüm bu eserlerden fark1, şüphesiz ki Edgar Allan Poe'nun dehası ile yeni bir edebi tür olan polisiye kurguyu ortaya çıkartmasıdır. Poe, zeki kriminolog C. Auguste Dupin ile yeni bir yazın türünün doğmasına sebep olmuş, birçok yazarı etkileyerek Sherlock Holmes ve Hercule Poirot gibi önemli karakterlerin şekillenmesine, edebiyat dünyasına kazandırılmasına da yardım etmiştir (18). Sherlock Holmes'un yaratıcısı Arthur Conan Doyle, ünlü dedektifi Sherlock Holmes'u yaratırken Poe'dan, Tıp Fakültesi'ndeki akıl hocası Dr. Joe Bell'den ve kendi yaşantısından etkilenmiştir (6). James OBrien'1n The Scientific Sherlock Holmes: Cracking The Case With Science and Forensics adlı eserinde değindiği üzere; Doyle, 22 Mayıs 1859'da Edinburgh'ta doğar. Bir Katolik olarak yetiştirilmesine rağmen, çok geçmeden Hristiyanlığa olan ilgisini kaybeder ve bu kaybın yerini bilim ve mantık doldurmaya başlar. Annesi tarafından kitap sevgisi aşılanan Doyle, bu dönemde, Poe'nun dedektif hikâyeleri dâhil tüm eserlerini okumaya başlar. 1876 'da Edinburgh Üniversitesi'nde almaya başladığı tıp eğitimi, ileride ünlü karakteri Sherlock Holmes'u ortaya çıkartan unsurlardan biri olacaktır; zira Sherlock Holmes hikâyelerinde bilimin varlığı açıça ortadadır. Tıp Fakültesi’ndeki eğitimi süresince kendisine akıl hocalığı yapmış olan Dr. Joe Bell de Doyle'u etkileyenlerdendir; Bell'in hastalar hakkında yaptığ 1 akıl yürütmeler, Holmes'un karakterini şekillendiren olgulardan biri hâline gelmiştir. Doyle, 1890 yılında, göz hekimliği alanında çalışmalar yapmaya gittiği Viyana'da bir ofis açar, fakat hiçbir hastanın muayene olmak için gelmediği ofisinde Sherlock Holmes hikâyelerini yazmaya başlar. İlk eseri Sherlock Holmes: Kızll Soruşturma 1887'de yayımlanır. Eserinde Dupin'i model seçmesine rağmen, karakteri Holmes farklıdır; zira Holmes öyle zekidir ki kimsenin farkına varamadığı gizemleri rahatça çözer. İlk Sherlock Holmes hikâyesi ile Amerika'da inanılmaz bir üne kavuşan Doyle'un üçüncü hikâyesi Sherlock Holmes: Bohemya'da Skandal, The Strand Magazine'de basılır ve Londra'da büyük beğeni ile karşılanır. Fakat sıkıldı ̆̆ için sekizinci hikâyede yok etmeye karar verdiği Holmes'u yirmi yedinci hikâyesi olan Sherlock Holmes: Son Vaka'da öldürür. Sherlock Holmes'un ölümü ile aldığı olumsuz eleştiriler yüzünden yirmi sekizinci hikâye Sherlock Holmes: Boş Ev ile Holmes'u dirilten Doyle, 7 Temmuz 1930'da öldüğünde, ardında ölümsüz bir karakter bırakır (6). Holmes'un bilimselliği, kimi meslektaşlarınca "ilk gerçek polisiye yazar" olarak tanımlanan R. Austen Freeman'in ilk polisiyesi Kırmızı Parmak Izi (1907)'nde de kendini belli eder. Freeman, Doyle'un akıl yürütmelerinde olduğu gibi, bilimselliği kullanır ve kriminolojik çalışmaların önemini vurgular. Yıllar geçtikçe teknoloji gelişecek, kriminolojik unsurlar olgunlaşacak ve polisiye dedektiflerinin kullandığı yöntemler değişecektir (19).

Polisiye roman kahramanları arasında ölümsüzlüğü yakalamış olanlardan biri de Hercule Poirot'tur. Hercule Poirot'un yaratıcisı Agatha Mary Clarrisa Miller ya da edebiyat dünyasında tanındığı hâli ile Agatha Christie, ekonomik durumu gittikçe kötüleşen üst sınıf bir ailenin üçüncü çocuğu olarak 1890 yılında Torquay'da doğar (20). Henüz küçük bir çocukken, kız kardeşi ile Doyle'un eserlerini okur ve dedektif romanı yazmanın zor olup olmayacağını düşünür (21). Archibald Christie ile evlenerek Rosalind adında bir çocuk dünyaya getiren Agatha Christie, ekonomik durumlarının kötüye gitmesi 
nedeni ile ilk romanı Styles 'taki Esrarengiz Vaka'yı yazar (20). 1920'de basilan bu roman, Hercule Poirot'un doğduğu eserdir. 1920'den 1973'e kadar birçok eser kaleme alan Agatha Christie'nin son eseri Kader Kapısı'dır. Dedektif Hercule Poirot'un yanı sira 1930 yılında yazdığı Ölüm Çığlı̆̆ adlı eseri ile edebiyata ve polisiye eserlere Miss. Jane Marple adında bir de kadın dedektif kazandırır. Önemli bir polisiye yazarı olan Christie'nin Poe ve Doyle'dan etkilenmemesi olası değildir. Zira henüz küçük bir çocukken Doyle'un eserlerini okumuştur ve Doyle'un Poe'dan esinlenerek eserlerine yansittığ 1 her benzerlikten Christie de nasibini almıştır. David I. Grossvogel, Essays on Detective Fiction'da yer alan Death Defferred: The Long Life, Splendid Afterlife and Mysterious Working of Agatha Christie adlı makalesinde, Christie'nin Doyle'dan esinlenmiş olduğu iki temel yaklaşımdan bahseder; bunlar, kırsal mekan seçimi ve beklenmedik unsurların kullanımıdır. Sherlock Holmes, kentsel yaşamı oldukça benimsemiştir, fakat birçok macerası kırsal alanda veya kırsal alanda yer alan konakların duvarları arasında gerçekleşmektedir. Ayriyeten Morgue Sokağı Cinayetleri'ndeki katilin beklenmedik bir şekilde orangutan çıkması gibi Doyle da Benekli Kordon'da katilini yılan yapmaktadır (21). Kendinden öncekilerden edindiği bilgileri eserleriyle harmanlayan Christie, tüm benzerliklerine rağmen, öteki yazarlardan farklıdır; zira eserlerinde öyle başarılı bir analiz yöntemi kullanır ki, kendisi katilin adını vermese de, okur katilin kim olduğunu tahmin edebilir. Christie'nin dedektif romanları "Altın Çağ” romanları statüsünde ele alınmaktadır; iki dünya savaşı arasında denk geldiğimiz Altın Çağ dönemi yazarları, şiddeti tüm detayları ile yansıtmaktansa eserin arka planında kullanmayı, bir muhakeme süreci yaratabilmeyi hedeflemektedir (22).

Polisiyenin popülerleşmesi ile güzel bir polisiyenin nasıl oluşturulması gerektiğine dair fikirler de gündeme gelmeye başlar. Kendisi de bir polisiye yazarı olan, eleştirmen Willard Huntington Wright, S. S. Van Dine takma adını kullanarak polisiye türünde yazmış ve polisiye yazarının izlemesi gereken yollar hakkında bir çalışma ortaya koymuştur (1). S. S. Van Dine, kendi gizem öykülerinin de yer aldığı Philo Vance Omnibus, Volume I adlı eserde, polisiye türü yazarlarına yirmi maddelik bir yol gösterici hazırlamıştır (23). Dine'ın hazırladığı bu yirmi maddelik çalışma, 1928 yılında American Magazine'de yayımlanmıştır (1). S. S. Van Dine'a göre, okuyucu ve dedektif eşit olmalıdır ve suça ilişkin tüm ipuçları esere ustalıkla yansıtılmalıdır. Yazar okuyucuyla oyun oynamamalı, okuyucuyu bilinçli şekilde aldatmaya çalışmamalıdır. Eserde aşka yer verilmemelidir; aşkı polisiyeye karıştırmak, entelektüel bir deneyimi gereksiz duygu- larla mahvetmekten başka bir şey değildir. Dedektif ya da suç araştırmacıları asla gerçek suçlu olarak planlanmamalıdır; bu kişilerin eserde suçlu rolünü üstlenmesi sahtekârlıktan ibarettir. Suçlu, kazara ya da rastlantı sonucu değil, akıl yürütmelerle bulunmalıdır; suçluyu kazara ya da rastlantı sonucu bulmak okura boşa kürek çektirmek anlamına gelir. Eserde mutlaka bir dedektife yer verilmelidir ve dedektif, ipuçlarını toplayarak sonuca ulaşan, böylece son bölümde kötü karakteri yakalayandır. Polisiyelerde bulunması gereken en önemli şey cesettir; ölümden başka bir suçun üç yüz sayfada anlatılması kuru gürültüdür. Suç tamamıyla zihinsel süreçler aracılığı ile çözülmelidir; okur, metafiziksel olguları kullanan, ruhlar âlemi ile uğraşan bir dedektifle boy ölçüşemez ve baştan kaybeder. Eserde sadece bir tane dedektif olmalı ve bu dedektif "deus ex machine” -olağanüstülüğü ile sorunu çözen tanr1- görevi görmelidir; birden fazla dedektifin bir araya gelmesi hem okurun esere olan ilgisinin yitmesine sebep olur hem de yönlendiricisinin kim olduğunu algılayamamasıyla sonuçlanır. Suçlu, eserde yer alan, okurun tanıdığı biri olmalıdır. Yazar, suçluyu olay mahallindeki hizmetlilerden (kahya, uşak, avlak bekçisi, aşçı vb.) seçmemelidir; zira bu kolaylıkla bulunabilir bir sonuçtur, fail hiç tahmin edilemeyen biri olmalıdır. Suç ne kadar çok olursa olsun, fail yalnızca bir kişi olmalıdır; faile yardım eden birileri olabilir, fakat önemli olan, okurun öfkesinin bir kişi üzerine odaklanmasıdır. Eşkıyalık, mafyalık gibi çeşitli statülerin polisiyelerde işi yoktur. Suçun uygulanışı da araştırılması da akla ve bilime uygun olmalıdır; sözde bilimsel, hayali, kurgusal olgular polisiye romancıllı̆ında kullanılmaz. Gerçek, okurun algılayabileceği açıklıkta olmalıdır; böylelikle okur, eseri yeni baştan okursa, her ipucunun zanliya işaret ettiğini ve dedektif kadar yetenekli olsa, sonuca dedektif kadar hızla ulaşabileceğini anlar. Dedektif romanında uzun tanımlamalar yapılmamalı, edebi unsurlara çok yer verilmemeli, derinlemesine karakter analizleri oluşturulmamalıdır; yazarın okura karakterler hakkında ilgi ve sempati kazandırması yeterlidir çünkü polisiye okurları, polisiyeyi edebi gösteriş, güzel tanımlamalar ve duyguların izdüşümü için değil, mantıksal bir süreç takip edebileceği entelektüel bir aktivite gerçekleştirmek için okur. Hırsızlık ve eşkıyalık dedektiflerin değil, güvenlik güçlerinin çalışma alanına girer; dolayısıyla polisiye eserde işi yoktur. Eserde araştırılan, intihar ya da kaza sonucu oluşmuş olmamalıdır; bu, okurda geri dönüşü olmayan bir hayal kırıklığı yaratacaktır. Dedektif öykülerinde rastlanan suçların motivasyonu kişisel olmalıdır; anlatılan, okurun her gün deneyimlediği olguları yansıtmalıdır ve bastırdığı arzu ve hisler için açık kapı bırakmalıdır. Suçlunun suç mahallinde bıraktığı sigara 
izmaritini şüphelinin sigara markası ile karşılaştırmak, yapmacık metafiziksel yöntemlerle şüpheliyi korkutarak kendisini ele vermesini sağlamak, sahte parmak izleri, suç anında başka bir yerde olunduğuna dair ifade, şüpheliyi görünce havlamayan ve şüphelinin tanındığına kanıt köpek, suçun şüpheliye çok benzeyen birine ya da şüphelinin ikizine yıkılması, şırınga ve ilaç kullanımı, suçun kapalı bir odada polisin gelişinden hemen sonra işlenmesi, suça atıfta bulunan kelimelerle ilgili çağrışım testi, dedektifin çözdüğü parola ya da şifre gibi unsurlar polisiye yazarlarınca kullanılmamalıdır; zira bunlar sıklıkla kullanılmıştır ve okurlar tüm bu unsurlara aşikârdır. Yazar bu olguları kullandığ orijinallikten uzak oluşunu ifade etmiş olur (23). S.S. Van Dine'ın yirmi polisiye kuralı, polisiye yazını için bir çerçeve mahiyetindedir ve S. S. Van Dine'dan sonra Ronald A. Knox ve François Fosca da kendi geliştirdikleri kurallar bütününü oluşturacaklardır. 1920 - 1940 yıllar1 arasında yazılmış olan eserlerin bu kurallara uyduğu belirlenmiştir, polisiye yazarlarının bu maddelere henüz kurallar konulmadan önce dikkat ettiği ise ilgi çekici bir noktadır (1).

Dünya edebiyatına Morgue Sokağı Cinayetleri ile kazandırılan polisiye, Türkiye'de Morgue Soka$\breve{g l}$ Cinayetleri'nden kırk yıl sonra, Fransız Ponson de Terrail'in yazmış olduğu Paris Facialarl'nın Ahmet Münif tarafından 1881 yılında yapılan çevirisi ile ortaya çıkmıştır. Üyepazarc1, Türkiye'nin polisiye serüvenini dönemlere ayırır ve polisiye gelişimini bu evreler içerisinde inceler; Üyepazarcı'ya göre, Türk polisiyesinin ilk dönemi 1883 - 1928 yılları arasıdır. 1883 - 1928 yılları, Osmanlı Devleti'nde yaşanan önemli gelişmeleri hatırlatmaktadır (24). Bu gelişmeler, elbette, Tanzimat Dönemi'ni ifade eder. Tanzimat'tan Cumhuriyet'e Türkiye Ansikolopedisi Cilt l'de Bülent Tanör'ün ifade ettiği gibi, kimi tarih çalışmacılarına göre Tanzimat Dönemi 1860 'ta başlayarak II. Meşrutiyet'in ilanına kadar (1908) sürmüş, kimi tarih çalışmacılarına göre ise 1839 Gülhane Hatt-1 Hümayûnu ile başlayıp 1870'li yılların başlarına kadar devam etmiştir (25). Görüldüğü üzere, Tanzimat Dönemi, Erol Üyepazarcı'nın polisiye gelişim evrelerinin içinde yer almaktadır. Tanzimat Dönemi, devletin vaktiyle benimsediği yaklaşımların çürümüş yanlarını onarmayı ve devletin kalkınmasını hedeflemektir. Ortaya çıkışlarında "Batılılaşma" politikasının etkili olduğu "Osmanlı Aydınları"nın (26) benimsediği bu reform hareketi, kişisel özgürlük ve dokunulmazlık konusunda yapılacak hukukî düzenlemeler yolu ile siyasal birliği sağlamayı ve böylece devlet bünyesinde varlığını sürdüren, fakat dağılmış kitleleri yeniden bir araya getirmeyi planlamıştır (25).
Tanzimat Dönemi'nde yapılan reform hareketleri, kaçınılmaz olarak yazınsal eserleri da etkilemiştir. Tanzimat Dönemi gelişmeleri devam ederken, bu gelişmelerin neler olduğunu gösterecek, devletin sınırlarını ortaya çıkartacak bir devlet sözcüsü yaratılmıştır. Bu, projesini II. Mahmud'un geliştirdiği Takvim-i Vakâyi gazetesidir ve gazetenin Arapça, Farsça, Fransızca, Rumca, Ermenice, Bulgarca nüshaları bulunmaktadır. Takvim-i Vakâyi gazetesine ek olarak, 1840'tan sonra Ceride-i Havadis gazetesi ortaya çıkmış ve bu iki gazete dönemin düşünürlerinin yetiştirilmesi noktasında bir okul görevi üstlenmiştir (27). Ceride-i Havadis, İstanbul'da ikamet eden bir İngiliz olan William Churchill tarafından çıkartıldığ için sadece devlet sözcülüğü yapma görevi üstlenmemekteydi; bu da Ceride-i Havadis'in sosyal yaşama dair konuları da paylaşabilmesi, Batılılaşma'dan bahsedebilmesi ve Avrupa'nın örnek alınmasının öneminden dem vurabilmesi anlamına geliyordu (28). Ceride-i Havadis gazetesinde çevirilere, Türkiye'ye gelen tiyatro eserlerine, bu eserlerin özetlerine de yer verilerek Batılaşma hareketine destek olunmaktaydı; tiyatro türü üzerine yazılmış olan bir makaleyi yayımlayan ilk gazete de Ceride-i Havadis olmuştur (29). Tanzimat Dönemi gazeteleri edebiyatla iç içe idi; zira çoğu yazar, dönemin gazeteciliğini yapmakla kalmıyor, yazdıkları çoğu edebi eser gazetelerde basılıyordu. Bu yazarlar arasında öne çıkan örnekler Şinasi, Ziya Paşa, Namık Kemal, Ali Suavi, Ahmet Midhat, Ebuzziya Tevfik, Şemsettin Sami idi (30). Tanzimat Dönemi'nde cinai eserlere olan ilgi büyüktü, zira gazeteler, okur sayılarını artırabilmek için ilgi çeken eserlerin çevirisini yaptırıyor ve yayımlıyordu (31).

Polisiye alanında Türk edebiyatına en önemli destek Ahmet Midhat Efendi'den gelecektir, zira Ahmet Midhat Efendi, Esrârı Cinâyât (1884) adlı eseri ile Türk edebiyat tarihinin ilk polisiyesini yazan kişidir (24). İstanbul Boğazı'nın Karadeniz'e açılan kısmında, Rumeli sahiline yakın duran "Öreke Taşı” adındaki kayalığın üzerinde üç ceset bulunur; gazetelerde çıkan cinayet haberinin ardından, zeki dedektif Osman Sabri, arkadaşı kılık değiştirme üstadı Necmi ve onlara kurbanlardan birinin üzerinden çıkan metnin çevirisini yaparak yardım eden bir gazetecinin cinayeti çözme aşamaları, eserde ustalıkla anlatılır (32). Edebiyat tarihimizin önemli yazarlarından biri olan Ahmet Midhat Efendi, kendi yapmış olduğu çevirilerin ve Batılı yazarların etkisinde kalmış, yine de eserlerinde yerel unsurları kullanmaktan vazgeçmemiş ilk yazardır (33). Dolayısıyla, Türk edebiyatının ilk polisiyesi Esrârı Cinâyât' 1 yazarken Batı'dan etkilenmiş olduğunu söylemek yanlış olmayacaktır. Zira "adli romancı" adını verdiği Emile Gaboriau'nun polisiyelerinden biri olan $L e$ Crime d'Orcival' 1 çevirisini 1884 'te yapar ve bu eserin 
etkisi ile edebiyatımızın ilk polisiye romanı olan Esrâr Cinâyât (1884)'ı da aynı dönemde yazar (34).

Türk polisiyesine Ahmet Midhat Efendi kadar destek olan bir başka isim ise II. Abdülhamid'tir (35). II. Abdülhamid, 22 Eylül 1842'de doğmuştur (36). Babası I. Abdülmecid, annesi ise Tiri Müjgan'dır (37) ve I. Abdülmecid'in ikinci oğludur (36). Joan Haslip, The Sultan: The Life of Abdul Hamid II adlı eserinde, II. Abdülhamid'in çocukluğu hakkında bilgiler verir. Abdülhamid'in annesi Tiri Müjgan'ın rahatsızlığı, babas1 I. Abdülmecid'i uzaklaştırmış; bu uzaklık tüm gününü odasında geçiren Tiri Müjgan hakkında çeşitli söylentilerin yayılmasına neden olmuştur. Annesini Harem'deki odasında ziyaret eden Abdülhamid, dedikodu ve entrikanın içinde büyümüş, bu durum onun herkese şüphe ile bakmasına sebebiyet vermiştir (38). Tiri Müjgan otuz üç yaşında veremden vefat ettiğinde, Abdülhamid henüz on yaşındadır. Dönemin bir özelliği olarak, çocuk sahibi olamamış ya da çocuğu ölmüş padişah eşleri, annesi vefat eden padişah çocuklarının manevi annesi olmaktadır; Abdülhamid de annesinin ölümünün ardından Rahîme Perestû'nun bakımına verilir (36). Vakti zamanında oğlu Abdülaziz'in tahta çıkması için verdiği uğraşlar yüzünden davranışları dikkatle takip edilen Pertevniyal Valide Sultan ile de oldukça yakındır. Pertevniyal ve Abdülhamid, birlikte geçirdikleri zamanlarda kitap okuyarak, esrarengiz olay ve olguları anlamlandırmaya çalışırlar (38). Abdülhamid, sanatı ve edebiyatı sevdiği kadar, insan davranışlarını incelemeyi ve insanların kişilikleri ile zaaflarını ortaya çıkarmayı da sever. Babası I. Abdülmecid, oğlunu "kuşkucu ve suskun" olarak adlandırır ve Abdülhamid'in şüpheci ve suskun tavrını bu şekilde açıklar (36). Abdülhamid, büyüdüğünde de gizem tutkusundan vazgeçmeyecek, hatta amcası Abdülaziz'in ölümünün intihar olmadığını, bu ölüme intihar demenin adli tıbbı açıdan doğru olamayacağını, tıpkı İsmail Hami Danişmend'in İzahlı Osmanl Tarihi Kronolojisi Cilt 1'de otuz bir madde ile açıkladığı gibi yorumlayacaktır (39). Abdülhamid'e göre, intihar eden bir bireyin aynı anda iki kol damarını birden kesmesi mümkün değildir ve bu, yıllar evvel kimi yazarlarca açıklanmıştır (40).

II. Abdülhamid, 1876 'da tahta çıktığı zaman, amcas1 Abdülaziz ile yaptığı Avrupa seyahatinin de etkisi ile Batı'daki gelişmeleri takip etmeye ve böylece Osmanlı Devleti'nin bekasını güçlendirmeye çalışır. Yıldız Saray'ında kurdurduğu Kütübhane-i Hümayun'u, birçok kütüphane izleyecek ve böylece kültürel ve bilimsel ilerlemeler takip edilebilecektir. Lâkin II. Abdülhamid, yönetiminin sorgulanmasından rahatsız olan ve yoğun kontrol takıntısı bulunan bir padişahtır; dolayısıyla, ülke içerisindeki yazarlar, sansür baskısı altındadır ve sansür yüzün- den eser üretmekte zorlanırlar. İşte tam bu noktada, sansür baskısının bir getirisi olarak, çeviri eserler öne çıkar ve bu eserler arasında macera öyküleri, bilim-kurgu ve polisiye romanlar yer alır (41). Polisiye türünde okuduğu ilk eser olan Sherlock Holmes: Boş Ev Vakası onu büyülemiş, Sherlock Holmes'un yazarı Sir Arthur Conan Doyle'a ait tüm eserleri kendisine göndermesi için Londra Sefiri Musurus Paşa'yı görevlendirmiştir (42). Tahtta kaldığı otuz üç y1l boyunca (37), Sultan II. Abdülhamid'in altı bin adet polisiye roman çevirttiği, 31 Mart Vakası sonucunda bu eserlerin yağmalandığı belirtilmektedir (35). Çocukluğunda yaşadığı travmalara ek olarak, II. Abdülhamid'in Karındeşen Jack'e olan yoğun ilgisi de polisiye sevgisine etki etmiştir. İngiltere'nin oldukça ses getiren seri katili Karındeşen Jack'i bulması için Abdülhak Hamid'i görevlendiren ve kendisine Hazine-i Hassa'dan ödeme yapan II. Abdülhamid, 1907 yılında, İstanbul'da, Doyle ile görüşmüş ve kendisine Mecidiye Nişanı'nı armağan etmiştir (42). II. Abdülhamid'e olan desteği aşikâr olan Ahmet Midhat Efendi'nin (43) tarihimizin ilk polisiyesi olan Esrârı Cinâyât (1884)'1 yazarken II. Abdülhamid'in polisiye sevgisini göz önünde tutmuş olabileceği de söz konusudur. Dolayısı ile ne kadar sansasyonel bir yönetim sistemi benimsemiş olursa olsun, II. Abdülhamid, polisiye kültürüne renk veren simalardan biridir.

Ahmet Midhat Efendi'den sonra polisiye kurgusunu kullanan bir diğer isim, Arsene Lupin çevirmeni Fazlı Necip, Cani Mi Masum Mu? (1901) adında bir polisiye yazar. II. Meşrutiyet (1908)'ten sonra, Amerika'da “dimenovel” adı ile tanınan, Türkçe'de "onparalık öyküler" olarak bildiğimiz macera öyküleri edebiyatımıza giriş yapar ve bu türün başını çeken yazar, 1913'te hayat verdiği Türklerin Şerlok Holmes'u Amanvermez Avni'si ile Ebüssüreyya Sami olur. Hüseyin Nadir de "onparalık öyküler"den nasibini alacak ve 1921 'de yarattığı Fakabasmaz Zihni ile bu türe başka bir kahraman armağan edecektir. Fakat "onparalık öyküler" listesinin en gözde kahramanı Cingöz Recai' dir ve unutulmaz kahraman Cingöz Recai'nin yaratıcısı Server Bedi, yani Peyami Safa olacaktır. II. Meşrutiyet'in ardından telif polisiye romanın önemi artar ve Yervant Odyan, hakkında çok konuşulan eseri Abdülhamit ve Şerlok Holmes (1912)'u bu dönemde kaleme alır (24). Eser, II. Abdülhamid devrinin ağır bir eleştirisi ve tüm Osmanlı vatandaşlarının bir arada yaşayabileceği güzel bir dünyanın çağrısı mahiyetindedir (44).

Tanzimat Dönemi Edebiyatı'nı Servet-i Fünûn Dönemi Edebiyatı takip eder. Servet-i Fünûn edebiyatçıları, II. Abdülhamid'in baskıcı tutumundan dolayı oldukça s1kılmış aydınlardır (45). Bu sıkıntıdan kurtulabilmek için kaçış planları yapan Servet-i Fünûn yazar ve şairlerinin ortak özelliği, bu "kaçış" olgusunun beraberinde getirdiği 
buhran hâlidir (46). Servet-i Fünûn yazarlarından Mehmet Rauf, 1920'li yıllarda Define ile Kan Damlası adını verdiği iki polisiye yazar (24).

Milli Edebiyat Dönemi'ne gelindiğinde, Sherlock Holmes ve Arsene Lupin'i örnek alan bir sistemin geliştiği, telif polisiyeye geçişin söz konusu olduğu görülür; bu dönemde özgün eser veren yazar bulmak bir hayli zordur. Cumhuriyet Dönemi yazarları arasında da polisiye üzerine eser veren birçok değerli isim bulunmaktadır ve bu isimlerin başında Halide Edip Adıvar gelir. Halide Edip Adıvar, Cumhuriyet Dönemi edebiyatımızın ilk kadın polisiye yazarıdır ve Yolpalas Cinayeti (1937) adını verdiği roman ile türe yeni bir değer kazandırmıştır. Cumhuriyet Dönemi'nin ses getiren bir başka kadın polisiye yazarı Zühal Kuyaş’tır; Kraliçe'nin Şamdanları, Kartal Yuvası gibi polisiye eserler veren yazarın Sonuncu Oda adlı polisiye eseri orijinalliğini korumakta ve tam anlamıyla bir polisiye roman özelliği taşımaktadır. Nâzım Hikmet'in Yeşil Elmalar'ını (1936) ve Hüseyin Rahmi Gürpınar'ın Utanmaz Adam'1 (1934) ile Eşkıya Ininde'sini (1935) de unutmamak gerekir (47).

Edebiyatımızda polisiyenin ilerleyememesinin, özgünleşememesinin temel nedeni, bu türdeki eserlerin ciddiyetsiz bulunmasıydı; öyle ki Peyami Safa ve Kemal Tahir polisiye türündeki romanlarının yazarlığını üstenememiş ve takma isimler kullanmışlardı (31). Ünlü yazarlarımızdan Kemal Tahir, 1950’lerde, Mikey Spillane'nın Mike Hammer öykülerini dilimize çevirmiş, bir müddet sonra, F.M. takma adı ile kendi suç konulu romanlarını yazmaya başlamıştır (48). Kemal Tahir, kahramanı Sam Krasmer'1 yaratmış ve Mike Hammer öykülerini yazmayı bırakmıştır; Muzaffer Ulukaya takma adı ile Kemal Tahir'in Mike Hammer öykülerini bıraktığı yerden devralan ise Afif Yesari'dir (49).

1980'lerle birlikte, polisiye içeriği başkalaşım geçirmeye başlar (31). Zira Ahmet Midhat Efendi ile başlayan polisiye kültürümüzün ilk konumu İstanbul iken (43), 1980 sonrası yazarları memleketin farklı köşelerini de suç anlatısında kullanırlar (31). 1990'lara gelindiğinde, Türk polisiye kültürüne yaptığı katkıları ile bilinen Osman Aysu karşımıza çıkmaktadır. 1994 yılında ilk romanı Havyar Operasyonu'nu yazan Osman Aysu, eserlerinde uluslararası olaylardan, seri katillerden, haberlerden ve MiT (Milli İstihbarat Teşkilatı) raporlarından esinlenir. Polisiye üzerine birçok eser veren Aysu'yu diğer polisiye yazarlarından ayıran, konuyu ustaca işleyişi ve soruşturma ile çözümleme evrelerine kattığı özgün bakış açısıdır. Eserlerinde çokça değindiği MiT, Aysu'nun teşkilata olan yakınlığını sorgulatmış ve Aysu'nun eserlerine olan ilgiyi artırmıştır. Osman Aysu, Türk polisiye kültürüne yerleşen Batı edebiyatı karakterlerinden farklı karakterler yaratmış ve olay örgüsünü de yine Batı polisiyesinden ayrı tutmuştur; bu durum, Aysu'ya ait eserlerin önemine dair bir başka vurgu mahiyetindedir (50). 1990'ların önemli polisiye yazarlarından biri de Ahmet Ümit'tir. Ahmet Ümit'in ilk romanı Sis ve Gece, 1996 yılında yayımlanmış ve Türk polisiyesine değer kazandırmıştır (51); zira polisiye türüne örnek gösterilebilecek olan Sis ve Gece, Yunanistan'da yayımlanır ve yabancı dile çevrilen ilk Türk polisiyesi olur (52). Agatha'nın Anahtarı adını verdiği polisiye hikâye kitabını 1999'da yayımlamış olan Ümit, 2000 yılında Patasana adlı romanını yayımlamışırı (51). Agatha'nın Anahtarı'nda Türkiye'de meydana gelmiş olan suçları ve bireylerin bu suçlara karşı geliştirdiği tepkiyi aktaran Ahmet Ümit, Patasana'da insanoğlunun içinde yaşayan şiddet olgusuna değinir ve şiddet yoluyla ortaya çıkan cinayetlerden örnekler verir. Polisiye türünde verdiği çokça eserin ardından, 2005 y1lında Başkomiser Nevzat Çiçekçi’nin Ölümü adlı eseri ile bir ilke imza atan Ümit, polisiye ile çizgi roma$\mathrm{n} 1$ bir araya getirmiştir (52). Çok satan polisiyeleri Behzat Ç: Bir Ankara Polisiyesi, Her Temas İz Bırakır (2006) ve Behzat Ç: Son Hafriyat (2008) ile Ankara'da yaşanan suçları araştıran Behzat Ç. ve ekibinin yaşantısını anlatan Emrah Serbes, polisiye kültürü açısından farklı bir örnek oluşturur. Mehmet Murat Somer'in Hop-Çiki-Yaya adını verdiği serisinde karşımıza çıkan dedektif, bir travestidir; bu durum, Türk polisiyelerinde karşılaşılan karakterlerin değişimine örnek oluşturmaktadır (31). Polisiye türünde verilen özgün eserlerden biri diğeri ise, şüphesiz, Aziz Hatman tarafindan yazılmış olan Son Teşebbüs: Siyasi Cinai Gastro'dur (2015). Komünist bir evreni anlatan Hatman, devletin, polis gücünün ve çalışma zorunluluğunun var olmadığı, eşitlik duygusunun hâkimiyetini koruduğu bir dünyaya değinir. İşlenen en son cinayetin üzerinden uzun zaman geçmiş olmasına rağmen, yeni bir olası cinayetle karşı karşıya kalan ve bu cinayeti önlemeye çalışan kahramanlar yaratan Aziz Hatman, farklı bakış açısıyla Türk polisiyesine yeni bir soluk getirmiştir (53).

Polisiye romanlar Poe ile dillenmiş olsa da, insanoğlunun yaşantısında tutmuş oldukları yer, örneklerle açıklandığ 1 üzere, çok daha eski zamanlarda başlar. Şiddetin doğurduğu suç olgusu, insanların merak etmesine neden olur ve insanları şiddetin nedeni ve sonucunu incelemeye teşvik eder. Sadece gerçek hayatta değil, sanatta da kendini açık eden bu merak, polisiye romanların gün geçtikçe daha çok gelişmesine ve polisiye alanında birçok değerli yazarın değişik eserler ortaya çıkartmasına sebebiyet vermiştir. Dolayısı ile şiddet ve şiddet ile bağlantılı gelişen suç olgusu dünya üzerinden silinmediği takdirde polisiye eserlerin sonunun geleceğini düşünmek doğru olmayacaktır. Zira her suç, farklı motivasyonla oluşur ve farklılık merak uyandırır; bu merak yazarı etkiler ve böylece yepyeni bir eser ortaya çıkar. 


\section{Kaynaklar}

1. Şahin, S. Cinai Meseleler: Osmanl1- Türk Polisiye Edebiyatında Biçim ve İdeoloji (1884-1928), İletişim Yayınları, İstanbul. 2017; 9 - 30.

2. Mizikyan, A. Crime, Detection, and the Restoration of Order: A Study in Wilkie Collins's The Moonstone, Litera: İstanbul Üniversitesi Edebiyat Fakültesi Batı Dilleri ve Edebiyatları Dergisi, No: 16, İstanbul, 2004;105.

3. Poe, E. A. The Murders in the Rue Morgue, Vintage Classics, London, 2009; 3-35.

4. Bayram, E. G. Türkiye'de Polisiye Roman: Osman Aysu Romanları, Yüksek Lisans Tezi, Ankara Üniversitesi, 2004; 18.

5. Terrill, R. J. World Criminal Justice Systems: A Survey (Seventh Edition), Anderson Publishing, New Jersey, 2009; 9-119.

6. O'Brien, J. F. The Scientific Sherlock Holmes: Cracking The Case With Science and Forensics, Oxford University Press, 2012; 6-12.

7. Gendrot, S. B. The Social Control of Cities: A Comparative Perspective, Blackwell Publishers, The United Kingdom, 2000; 28-64.

8. Monkkonen, E. H. Police in Urban America: 1860 - 1920, The Press Syndicate of The University of Cambridge, The United Kingdom, xiii.1981.

9. Kutsal Kitap: Eski ve Yeni Antlaşma (Tevrat, Zebur, İncil). (2009). Yeni Yaşam Yayınları, 4: 8.

10. Sophocles. Antigone, Oedipus The King \& Electra. Hall E., editör. Oxford University Press, ix.1994.

11. Shakespeare, W. Titus Andronicus. Wilson, J. D., editör. Cambridge University Press, 2009; New York.

12. Honan, P. Shakespeare: A Life, Oxford University Press, USA, 1998; 59-60.

13. Worthington, H. From The Newgate Calendar to Sherlock Holmes. Rzepka, C. J., Horsley, L. editörler. A Companion to Crime Fiction, Wiley-Blackwell Publishing, The United Kingdom, 2010;11-27.

14. The Newgate Calendar. Danachair, D., editör. The Newgate Calendar, The Ex-classics Project, 2009;10.

15. Harrington, W. Which The Justice, Which The Thief, Bobbs - Merrill, 1963; 827-837.

16. Morton, J.The First Detective: The Life and Revolutionary Times of Vidocq: Criminal, Spy and Private Eye, Ebury Press, Great Britain, 2004;2.

17. Panek, L. L. An Introduction to The Detective Story, Bowling Green State University Popular Press, Ohio, 1987; 8.

18. Bandy, W. T. (1964). Who Was Monsieur Dupin?. Modern Language Association, 1964; 79; 509-510.

19. Çelik, E. Batı Edebiyatında Polisiye Romanın Gelişimi Sürecinde Düşünsel ve Sosyal Etkiler. Hacettepe Üniversitesi Sosyolojik Araştırmalar Dergisi, 2015; 6-8.

20. Rowland, S. From Agatha Christie to Ruth Rendell: British Women Writers in Detective and Crime Fiction, Palgrave Macmillian UK, 2001; 60-64.

21. Grossvogel, D. I. Death Defferred: The Long Life, Splendid Afterlife and Mysterious Working of Agatha Christie. Bens- tock B., editör. Essays On Detective Fiction, The Macmillian Press, 1983; 1-17.

22. Bargainnier, E. F. The Gentle Art of Murder: The Detective Fiction of Agatha Christie, Bowling Green University Popular Press, Ohio, 1980; 6-9.

23. Van Dine, S. S. Twenty Rules for Writing Detective Stories, OMNIBUS, Philo Vance Investigates, 1928; 985-989.

24. Üyepazarc1, E. Türkiye'de Polisiye Romanın İlk Dönemi: 1883-1928, 221B Polisiye Dergisi, İstanbul, 2017; 28-30.

25. Tanör, B. Anayasal Gelişmelere Toplu Bir Bakış. Tanzimat'tan Cumhuriyet'e Türkiye Ansiklopedisi Cilt 1, İletişim Yayınları, İstanbul, 1985; 10-23.

26. Kılıçbay, M. A. Osmanlı Aydını. Tanzimat'tan Cumhuriyet'e Türkiye Ansiklopedisi Cilt 1, İletişim Yayınları, İstanbul, 1985; 55-56.

27. Koloğlu, O. Osmanlı Basını: İçeriği ve Rejimi. Tanzimat’tan Cumhuriyet'e Türkiye Ansiklopedisi Cilt 1, İletişim Yayınları, İstanbul, 1985; 68-84.

28. Akbulut, U. Osmanlı Basın Tarihine Bir Katk1: Gazetelerin Yayınlanma Amaçları Üzerine (1831-1876). Turkish Studies: International Periodical For The Languages, Literature And History of Turkish or Turkic, Volume 8/5 Spring, Ankara, 2013; 37-40.

29. Kudret, C. Tanzimat'tan Cumhuriyet'e Türk Edebiyat1. Tanzimat'tan Cumhuriyet'e Türkiye Ansiklopedisi Cilt 2, İletişim Yayınları, İstanbul, 1985; 392-393.

30. Akyüz, K. Modern Türk Edebiyatı'nın Ana Çizgileri (18601923), İnk1lap Yayınevi, 1965; 69-70.

31. Uğur, V. 1980 Sonrası Türkiye'de Popüler Roman. Prof. Dr. Mine Mengi Adına Türkoloji Sempozyumu Bildirileri Kitab1, Adana, 2012; 420-428.

32. Midhat Efendi, A. Esrârı Cinâyât, Türk Dil Kurumu Yayınlar1; 2000

33. Okay, O. Batılılaşma Devri Türk Edebiyatı. İhsanoğlu, E., editör. Osmanlı Medeniyeti Tarihi 1. Cilt, Feza Gazetecilik A. Ş., İstanbul, 1999; 82.

34. Şahbenderoğlu, İ. On Dokuzuncu Yüzyıl Okuruna Sunulan Âsâyiş - Bahş Bir Roman: Esrâr-1 Cinâyât. Journal of Language and Literature Studies, 2013; (08); 10.

35. Canatak, A. M. Postmodern Polisiye Roman Ve Pınar Kür'ün Bir Cinayet Romanı, A.Ü. Türkiye Araştırmaları Enstitü Dergisi, Erzurum, 2013; 226.

36. Öztuna, Y. II. Abdülhamid: Zamanı Ve Şahsiyeti, Ötüken Yayınlar1, 2008;17-25.

37. Kutlu, A. T. Kurtlar Sofras1: II. Abdülhamid, Nokta Kitap, İstanbul, 2016;15-16.

38. Haslip, J. The Sultan: The Life of Abdul Hamid II, London: Weidenfeld and Nicolson, 1973; 10-31.

39. Danişmend İ. H. İzahlı Osmanlı Tarihi Kronolojisi Cilt 1, Türkiye Yayınevi, 1947; 1557-1566.

40. Bozdağ, İ. Sultan Abdülhamid'in Hatıra Defteri, Truva Yayınları, İstanbul, 2009;24.

41. Anameriç, H. Sultan II. Abdülhamid Döneminde Kütüphane Kurumu Anlayışının Değişimi. Sultan II. Abdülhamid Sempozyumu: Sosyo - Kültürel Hayat - Sanat - Basın Bildiriler, Türk Tarih Kurumu, Ankara, 2014;103-111. 
42. Ayvazoğlu, B. 'Üdebânın Hakikî ve Müşfik Dostu' Sultan II. Abdülhamid'in Edebiyat ve Edebiyatçılarla İlişkileri. Gün, F., Erbay, H. İ., editörler. Sultan II. Abdülhamid Han ve Dönemi, TBMM Basımevi, 2017; 259-261.

43. Esen, N. Modern Türk Edebiyatı Üzerine Okumalar, İletişim Yayınları, İstanbul, 2012; 6-29.

44. Uslu, M. F. (2015). Armenian Literary Studies In Turkey And New Prospects, New Perspectives On Turkey, 2015;53;195.

45. Türk, H. Bir Servet-i Fünûn Yazarı: Yeni Zelanda Fikri ve Anadolu'ya Avdet. Turkish Studies: International Periodical For The Languages, Literature and History of Turkish or Turkic, Ankara, Volume 9/3, 2014;1500-1501.

46. Karabulut, M. Tevfik Fikret ve Cenap Şahabettin'in Şiirlerinde Melankoli, Turkish Studies: International Periodical For The Languages, Literature and History of Turkish and Turkic, Volume 10/2, Ankara, 2015;510-511.
47. Üyepazarcı, E. Polisiye Romanın Türkiye'deki Öyküsü (1929 - 1990), 221B Polisiye Dergisi, İstanbul, 2017; 36.

48. Sagaster, B. Detectives "alaturka": Crime Fiction in Turkey. K. M., editör. Intercultural Aspects in and around Turkic Literatures, 2006;139.

49. Uğur, V. 1980 Sonrası Türk Edebiyatında Popüler Roman, Yüksek Lisans Tezi, İstanbul Üniversitesi, 2009;166.

50. Bayram, E. G. Osman Aysu Polisiyeleri, İletişim,2005; 224-231.

51. Ilıcak, N. G., Başoğlu N. Investigation of Values in Ahmet Ümit's Tale Books. Karaelmas Journal of Educational Sciences, 2018; 90-91.

52. Gezer, H. Türk Edebiyatında Polisiye Roman ve Ahmet Ümit'in Polisiye Roman Kurguları, Yüksek Lisans Tezi, Süleyman Demirel Üniversitesi, 2006; 56-57.

53. Hatman, A. Son Teşebbüs: Siyasi Cinai Gastro, Esen Kitap, 2015; İstanbul. 